\title{
PENGARUH VARIABEL MAKROEKONOMI DAN HARGA SAHAM ASING TERHADAP INDEKS HARGA SAHAM GABUNGAN
}

\author{
R Safiroh Febrina ${ }^{1}$, Sumiati ${ }^{2}$, Kusuma Ratnawati ${ }^{3}$ \\ Fakultas Ekonomi dan Bisnis Universitas Brawijaya Malang ${ }^{123}$ \\ Email : radensfebrina@gmail.com
}

\begin{abstract}
This study aimed to analyze the effect of macroeconomic variables and foreign stock price on Jakarta Composite Index (JCI) in Indonesia Stock Exchange covering the data period from January 2008 to December 2015. The methodology applied initially used the standard time series techniques, Vector Autoregression (VAR). The result showed that JCI are influenced with the selected macroeconomic and foreign stock price. Increasing in industrial production index and inflation will increase JCI, but exchange rate (Rp/USD) will decreases it. Money supply (M2) and interest rate is found insignificant on JCI. Strait Times Index, Philippines Stock Exchange Index and Dow Jones Industrial Average are found positively and significantly influenced JCI. However, Nikkei 225 and Shanghai Composite Index negatively and significantly influenced JCI. Kuala Lumpur Composite Index and stock Exchange of Thailand insignificant influenced JCI. Our finding suggest that JCI can be influence by macroeconomic variables and stock price in develop country and countries that are in the same region.
\end{abstract}

\section{Keywords: Foreign Stock Price, Jakarta Composite Index, Macroeconomic Variables}

\begin{abstract}
Abstrak : Penelitian ini bertujuan untuk menganalisis pengaruh variabel makroekonomi dan harga saham asing terhadap indeks harga saham gabungan (IHSG) di Bursa Efek Indonesia selama periode penelitian Januari 2008 - Desember 2015. Penelitian ini menggunakan metode analisis times series, Vector Autoregresi (VAR). hasil menunjukka bahwa IHSG dipengaruhi oleh beberapa variabel makroekonomi dan harga saham asing. Peningkatan indeks produksi industri dan inflasi akan meningkatkan IHSG, namun peningkatan nilai tukar (Rp/USD) akan menurunkan IHSG. Strait Times Index, Philippines Stock Exchange Index dan Dow Jones Industrial Average secara positif dan signifikan mempengaruhi IHSG, sementara itu Nikkei 225 dan Shanghai Composite Index berpengaruh negatif dan signifikan terhadap IHSG. Kuala Lumpur Composite Index dan stock Exchange of Thailand tidak signifikan berpengaruh terhadap IHSG. Hasil temuan ini mengindikasikan bahwa IHSG merupakan harga saham yang dapat dipengaruhi oleh variabel macroekonomi dan harga saham baik yang berasal dari negara maju dan negara yang berada pada kawasan regional yang sama.
\end{abstract}

Kata Kunci: Harga Saham Asing, Indeks Harga Saham Gabungan, Variabel Makroekonomi 


\section{PENDAHULUAN}

Investasi adalah suatu komitmen yang dilakukan terhadap sejumlah aset seperti uang atau aset lain yang memberikan manfaat di masa depan (Bodie et al, 2014). Pasar modal menjadi salah satu media investasi jangka panjang yang efektif untuk menghimpun dana perusahaan, selain itu, melalui pasar modal investor dapat memperoleh keuntungan berupa dividen dan capital gain. Saham merupakan salah satu alternatif investasi yang menarik dalam pasar modal, berinvestasi di pasar saham seorang investor membutuhkan indeks harga saham sebagai sebuah indikator untuk mengamati pergerakan harga dari sekuritassekuritas di pasar modal (Hartono, 2015).

Selama kurun waktu delapan tahun terakhir, kinerja IHSG dipengaruhi oleh beberapa hal, seperti perlemahan ekonomi global dan kondisi fundamental makroekonomi Indonesia. Perubahan IHSG mengindikasikan bahwa terdapat beberapa faktor yang mempengaruhi harga saham di Bursa Efek Indonesia. Faktor fundamental makroekonomi dianggap sebagai faktor dominan yang berkontribusi dalam pergerakan harga saham (Sirucek, 2012) hal ini dikarenakan faktor makroekonomi akan langsung direspon oleh investor dalam keputusan investasi di Bursa Efek Indonesia.

Bodie, et al (2014) menyatakan analisis faktor ekonomi harus dimulai dari ekonomi global. Ekonomi global dapat mempengaruhi prospek perusahaan, kompetisi harga dengan pesaing atau laba yang didapat dari investasi luar negeri dan harga saham perusahaan. Adapun beberapa variabel makroekonomi yang mempengaruhi IHSG diantaranya pertumbuhan ekonomi, inflasi, jumlah uang beredar, suku bunga, nilai tukar dan indeks harga saham asing.

Pertumbuhan ekonomi merupakan salah satu variabel terpenting dalam suatu negara, pertumbuhan ekonomi memiliki pengaruh dengan harga saham, oleh karena itu variabel ini merupakan salah satu faktor yang turut berpengaruh terhadap perubahan IHSG.

Menurut Mankiw (2012) Produk Domestik Bruto (PDB) menunjukkan pertumbuhan perekonomian suatu negara. Apabila PDB suatu Negara meningkat, maka perekonomian dan kesejahteraan Negara tersebut meningkat. Peningkatan PDB Sebagai pendekatan untuk mengukur pertumbuhan ekonomi dapat digunakan indikator lain, yaituindeks produksi industri seperti yang digunakan Naik dan Padhi (2012); Hussein et al (2012) dan Kalyanaraman dan Tuwarji (2014). Hal init dilakukan karena data PDB tidak tersedia dalam bentuk data bulanan.

Perkembangan jumlah uang beredar menunjukkan perkembangan ekonomi Negara. Kenaikan jumlah uang beredar meningkatkan jumlah uang yang dapat diinvestasikan (Naik dan Pahdi, 2012). Inflasi merupakan kecenderungan dari harga-harga untuk meningkat secara umum dan terus menerus (Mankiw, 2012). Kenaikan inflasi akan direspon investor dengan menahan laju investasi saham dan akan megalihkan investasi saham ke investasi non-risiko seperti tabungan atau deposito karena disaat terjadi inflasi, Bank Sentral akan pula meningkatkan suku bunga yang menjadikan investasi tabungan lebih menarik.

Nilai tukar dan suku bunga merupakan salah satu variabel terpenting dalam suatu negara yang menganut sistem perekonomian terbuka. Nilai tukar merupakan harga relatif dari suatu mata uang terhadap mata uang lainnya. Nilai tukar memiliki hubungan langsung dengan harga saham. Harga saham asing merefleksikan kondisi ekonomi Negara lain. Globalisasi dan integritas pasar modal yang terus meningkat menjadikan variabel ini memiliki hubungan langsung dengan harga saham domestik. Oleh karena itu variabel ini merupakan salah satu faktor yang turut berpengaruh dalam perubahan IHSG.

Penelitian Naik dan Padhi (2012) menunjukkan pertumbuhan ekonomi Negara dan jumlah uang beredar akan meningkatkan harga saham melalui peningkatan kinerja perusahaan dan minat investor dalam berinvestasi. Di lain pihak Ibrahim dan Musah (2014) menyatakan kenaikan jumlah uang beredar akan direspon oleh peningkatan inflasi yang akan berpengaruh negatif terhadap harga saham dan Hussin et al (2012) menyatakan peningkatan inflasi akan diikuti peningkatan saham sebagai langkah lindung nilai investasi. Hsing (2014) menyatakan harga saham merespon negatif pada perubahan suku bunga, namun Naik dan Padhi (2012) menyatakan suku bunga tidak selalu direspon oleh pelaku pasar serta Ho (2011) menyatakan harga saham lebih sensitif terhadap perubahan nilai tukar.

Krisis Amerika Serikat tahun 2008 yang menurunkan indeks Dow Jones Industrial 
Average, memberikan dampak yang sangat besar terhadap IHSG. Krisis tersebut menyebabkan IHSG melemah hingga 1.298 poin pada Desember 2008, yang sebelumnya mencapai 2.640 poin pada Januari 2008. Kabir dan Masih (2014) menyatakan indeks harga saham dari negara maju akan mempengaruhi harga saham negara lainnya, khususnya emerging market. Hal ini dikarenakan indeks harga saham dari negara maju mempunyai kekuatan dalam mempengaruhi perekonomian dunia. Disisi lain, Husnan (2015) menyatakan pasar modal dari negara yang berdekatan atau dalam satu kawasan regional dapat saling mempengaruhi pasar modal lainnya, dikarenakan adanya ikatan kerjasama perekonomian yang dapat saling mempengaruhi. Kalyanaraman dan Tuwarji (2014) menyatakan indeks harga saham Amerika Serikat (S\&P 500) tidak berpengaruh terhadap indeks harga saham di Saudi Arabia sedangkan Sikalao dan Lekobane (2014), Hsing (2014), Vardhan dan Sinha (2015) membuktikan bahwa harga saham asing Amerika Serikat (Dow Jones Industrial Average (DJIA))dan Jepang (Nikkei 225) mampu mempengaruhi harga saham di India dan Estonia.

Perbedaan hasil penelitian terdahulu menimbulkan pertanyaan, apakah harga saham di Indonesia juga merespon demikian atau bahkan menunjukkan hasil yang berbeda dengan penelitian sebelumnya. Selain itu, penelitian terdahulu hanya menggunakan indeks harga saham dari negara maju, sedangkan indeks harga saham dari negara yang letak geografisnya berdekatan dapat saling mempengaruhi. Jika mengacu pada perumusan masalah yang telah diuraikan sebelumnya, maka tujuan dari penelitian ini adalah menganalisis pengaruh makroekonomi dan indeks harga saham asing terhadap Indeks Harga Saham Gabungan (IHSG). Makroekonomi yang digunakan dalam penelitian ini meliputi indeks produksi industri, jumlah uang bereda, inflasi, suku bunga dan nilai tukar, sedangkan harga saham asing meliputi Kuala Lumpur Composite Index, Strait Times Index, Philippines Stock Exchange Index, Stock Exchange of Thailand Index yang mewakili harga saham kawasan ASEAN dan Dow Jones Industrial Average, Nikkei 225 Index, Shanghai Composite Index yang mewakili indeks harga saham dari negara maju. Penelitian ini menggunakan IHSG sebagai harga saham di Indonesia, karena IHSG telah mencakup keseluruhan saham di Indonesia.

\section{HIPOTESIS}

\section{Variabel Makroekonomi terhadap IHSG}

Indeks Produksi Industri (IPI) : Indeks produksi industri merupakan indeks yang mengukur produksi negara melalui pertumbuhan manufaktur. Peningkatan indeks produksi industri memberikan sinyal pertumbuhan ekonomi yang baik yang menunjukkan kinerja perusahaan yang baik sehinggameningkatkan harga saham. Menurut Mahakud dan Kumari (2015) struktur modal dan arus kas masa depan perusahaan secara langsung berhubungan dengan indeks produksi industri. Penelitian yang dilakukan oleh Naik dan Padhi (2012), Hussin et al., (2012) dan Kalyanaraman dan Tuwarji (2014) menyebutkan indeks produksi industri berpengaruh positif terhadap indeks harga saham.Oleh karena itu, penelitian ini menghipotesiskan indeks produksi industri berpengaruh positif terhadap IHSG.

Jumlah uang beredar : Jumlah uang beredar adalah jumlah uang yang berada pada masyarakat. Peningkatan jumlah uang beredar mengindikasikan peningkatan jumlah uang yang dapat diinvestasikan. Naik dan Padhi (2012) menyatakan peningkatan jumlah uang beredar dapat menghasilkan perubahan portofolio dari aset nyata ke aset keuangan. Penelitian yang dilakukan oleh Naik dan Padhi (2012), Kalyanaraman dan Tuwarji (2014), Ibrahim dan Musah (2014) menyatakan jumlah uang beredar berpengaruh positif terhadap harga saham. Oleh karena itu, maka dihipotesiskan jumlah uang beredar berpengaruh positif terhadap IHSG.

Inflasi : inflasi adalah peningkatan harga secara keseluruhan. Penelitian terdahulu menyatakan inflasi berpengaruh negatif terhadap IHSG (Naik dan Padhi; 2012, Kalyanaraman dan Tuwarji; 2014, Yu Hsing; 2014, Ibrahim dan Musah; 2014, Vardhan dan Sinha; 2015). Peningkatan inflasi akan meningkatkan biaya produksi perusahaan, apabila biaya produksi perusahaan lebih tinggi daripada peningkatan harga maka akan menurunkan profit perusahaan dan menurunkan harga saham (Tandelilin, 2010), sehingga dihipotesiskan inflasi berpengaruh negatif terhadap IHSG.

Suku bunga : Suku bunga memiliki hubungan negatif dengan harga saham (Jones, 2013). 
Penelitian Yu Hsing (2014) dan Ibrahim dan Musah (2014) menemukan pengaruh negatif suku bunga terhadap harga saham. Peningkatan suku bunga menjadikan alternatif non risiko seperti deposito dan tabungan menjadi lebih menarik, sehingga investor memindahkan dananya pada investasi non risiko tersebut dan turut menurunkan harga saham. Oleh karena itu dihipotesiskan suku bunga berpengaruh negatif terhadap IHSG.

Nilai tukar : Nilai tukar merupakan nilai suatu mata uang terhadap mata uang Negara lain. Depresiasi pada nilai tukar mata uang domestik akan menurunkan nilai dari return saham yang diterima investor.Depresiasi nilai tukar mata uang domestik juga akan meningkatkan return pada saham asing, hal ini akan mendorong investor untuk memindahkan dananya dari saham domestik ke saham asing dan akan menurunkan harga saham domestik. Penelitian yang dilakukan oleh Naik dan Padhi, 2012), Hussin et al., (2012), Sikalao (2014), Yu Hsing (2014) dan Kabir dan Masih (2014), menyatakan nilai tukar berpengaruh negatif terhadap indeks harga saham. Oleh karena itu, penelitian ini menghipotesiskan nilai tukar berpengaruh negatif terhadap IHSG.

\section{Variabel Harga Saham Asing terhadap IHSG}

Globalisasi perekonomian dan peningkatan integritas pasar modal antar negara menyebabkan perekonomian suatu negara dapat mempengaruhi perekonomian dan pasar finansial negara lainnya. Penelitian Kabir dan Masih (2014) menyatakan Nikkei 225 berpengaruh positif terhadap harga saham Malaysia, penelitian Vardhan dan Sinha (2015) menyatakan harga saham Amerika Serikat berpengaruh positif terhadap harga saham di India serta Pasaribu dan Kowanda (2013) menyatakan IHSG dipengaruhi oleh indeks harga saham Malaysia dan Filipina. Berdasarkan hal tersebut maka penelitian ini menghipotesiskan Kuala Lumpur Composite Index, Strait Times Index, Philippines Stock Exchange Index, Stock Exchange of Thailand Index, Dow Jones Industrial Average Index, Nikkei 225 Index dan Shanghai Composite Index berpengaruh positif terhadap IHSG.

\section{METODE}

Penelitian ini menggunakan jenis penelitian explanatory research. Sugiyono (2008) menyatakan explanatory research merupakan penelitian yang menguji hubungan sebab akibat antar variabel dengan pengujian hipotesis. Data yang digunakan dalam penelitian adalah data sekunder dalam bentuk bulanan. Data diperoleh dari Statistik Ekonomi dan Keuangan Bank Indonesia (SEKI-BI), OECD, Yahoo Finance dan Bursa Efek Indonesia. Data penelitian ini menggunakan Indeks Harga Saham Gabungan (IHSG) untuk harga saham, indeks produksi industri yang menunjukkan tingkat pertumbuhan ekonomi, data Indeks Harga Konsumen (IHK) sebagai proksi inflasi, data nilai tukar merefleksikan nilai tukar mata uang Rupiah per Dollar Amerika Serikat, BI Rate yakni variabel yang merefleksikan tingkat suku bunga acuan dan yang terakhir indeks harga saham Kuala Lumpur Composite Index, Strait Times Index, Philippines Stock Exchange Index, Stock Exchange of Thailand Index, Dow Jones Industrial Average Index, Nikkei 225 Index dan Shanghai Composite Index yang merefleksikan harga saham asing. Penelitian ini bersifat time series dengan periode penelitian dari Januari 2008 hingga Desember 2015 dengan 96 bulan amatan.

Penelitian ini menggunakan metode kuantitatif dengan pendekatan ekonometrika dengan metode analisis times series Vector Autoregression (VAR).VAR merupakan merupakan suatu sistem yang memperlihatkan setiap variabel sebagai fungsi linear dari konstanta dan nilai lag (lampau) dari variabel itu sendiri, serta nilai lag dari variabel lain yang ada dalam sistem (Siregar dan Irawan dalam Ajija, et al., 2011). Variabel penjelas dalam VAR meliputi lag seluruh variabel bebas dalam sistem VAR yang membutuhkan indentifikasi retriksi untuk mencapai persamaan melalui interpretasi persamaan. Lebih lanjut Ariefianto (2012) menjelaskan, analisa yang disediakan oleh model VAR bagi deskripsi data, peramalan, inferensi struktural, dan analisis kebijakan.Metode penelitian ini terdiri dari beberapa tahapan. Tahapan yang harus dilakukan adalah uji stasionaritas data, uji stabilitas, penentuan lag length, estimasi VAR untuk pengujian hipotesis.

Pengujian stasionaritas data atau biasa disebut dengan unit root test adalah hal yang penting dalam analisis data time series. Data yang stasioner akan mempunyai kecenderungan untuk mendekati nilai rata-rata dan berfluktuasi disekitar rata-ratanya (Gujarati, 2012). Data yang stasioner 
akan menunjukkan karakteristik rata-rata dan varians yang konstan serta nilai autokolerasi yang tidak terikat titik waktu (time invariant) (Ariefianto, 2012). Pengujian unit root dapat dilakukan dengan Augmented Dickey-Fuller (ADF) test pada derajat yang sama (level atau different) hingga diperoleh suatu data yang stasioner. Penentuan lag optimal adalah langkah yang sangat penting dalam model VAR. Lag yang terlalu sedikit atau pendek akan berpotensi menimbulkan masalah bias spesifikasi sedangkan jika terlalu banyak atau panjang akan menurunkan degree of freedom, dan dengan demikian estimasi menjadi tidak efisien (Ariefianto, 2012). Persamaan VAR yang telah dibentuk sebelumnya harus diuji stabilitasnya melalui VAR stability condition check. Jika nilai absolute atau modulus yang dihasilkan $<1$ maka model VAR dianggap stabil

Seluruh data yang digunakan pada penelitian ini merupakan data riil yang ditransformasikan ke dalam bentuk logaritma natural (LN) kecuali variabel yang sudah dalam satuan persen yakni suku bunga (BI Rate) dan inflasi kemudian dilanjutkan dengan Vector Autoregression (VAR). Semua tahapan analisis dilakukan menggunakan software E-views 9.

\section{HASIL}

Tahapan analisis dalam penelitian ini adalah uji stasioneritas data, uji stabilitas data dan penentuan lag length. Pengujian hipotesis menggunakan hasil estimasi VAR yang akan menghasilkan t-statistik yang kemudian akan dibandingkan dengan t-tabel. Pengujian stasionaritas data dalam penelitian ini menggunakan augmented Dickey-Fuller (ADF). Hasil menunjukkan seluruh data telah stasioner pada tingkat first difference I(1). Pengujian panjang lag length berdasarkan pada panjang lag terpendek yaitu, lag 1. Hasil uji stabilitas menujukkan nilai modulus $<1(0,12-0,99)$, yang mengindikasikan data telah stabil.

Tabel 1. Uji Stasioneritas Data

\begin{tabular}{ccccc}
\hline \multirow{2}{*}{ Variabel } & \multicolumn{2}{c}{ ADF } & \multicolumn{2}{c}{ Nilai Kritis Mc Kinnon 5\% } \\
\cline { 2 - 5 } & Level & $1^{\text {st }}$ difference & Level & $1^{\text {st }}$ difference \\
\hline IHSG & -1.032651 & $-6.304226^{*}$ & -2.892536 & -2.892536 \\
Indeks Produksi Industri & -0.204644 & $-10.62647^{*}$ & -2.892879 & -2.892879 \\
Jumlah Uang Beredar & 1.679309 & $-10.05812^{*}$ & -2.892879 & -2.892879 \\
Inflasi & -2.436233 & $-5.619033^{*}$ & -2.892536 & -2.892536 \\
Suku Bunga & -2.234868 & $-3.995595^{*}$ & -2.892536 & -2.892536 \\
Nilai Tukar & -0.634282 & $-4.273358^{*}$ & -2.893230 & -2.893230 \\
Suala Lumpur Composite Index & -0.671162 & $-7.198925^{*}$ & -2.892200 & -2.892536 \\
Strait Times Index & -1.540600 & $-6.771700^{*}$ & -2.892200 & -2.892536 \\
Stock Exchange of Thailand Index & -0.924393 & $-7.894883^{*}$ & -2.892200 & -2.892536 \\
Philippines Stock Exchange Index & -0.245557 & $-7.811483^{*}$ & -2.892200 & -2.892536 \\
Dow Jones Industrial Average & 0.034781 & $-7.966813^{*}$ & -2.892200 & -2.892536 \\
Nikkei 225 & -0.007506 & $-8.334128^{*}$ & -2.892200 & -2.892536 \\
Shanghai Composite Index & $-2.975388^{*}$ & $-7.073282^{*}$ & -2.892536 & -2.892536 \\
\hline
\end{tabular}

Dari hasil uji estimasi VAR pada Tabel 2 diketahui dari t-stastistik dari indeks produksi industri (3.28601), inflasi (2.63357) dan nilai tukar (-3.17559) lebih besar dari t-tabel (1.66196), yang menunjukkan indeks produksi industri signifikan dan positif mempengaruhi IHSG sedangkan nilai tukar diketahui signifikan dan negatif mempengaruhi IHSG. Jumlah uang beredar dan suku bunga diketahui tidak signifikan mempengaruhi IHSG. Hasil ini mengimplikasikan beberapa variabel makroekononomi mampu mempengaruhi IHSG dan bahwa investor tetap memperhatikan beberapa variabel makroekonomi sebagai strategi dalam keputusan investasi. 
Tabel 2. Estimasi VAR model variabel makroekonomi terhadap IHSG

\begin{tabular}{cccc}
\hline Variabel & Koefisien & t-Statistik & Keterangan \\
\hline Indeks Produksi Industri & 0.001518 & $3.28601^{*}$ & Signifikan \\
Jumlah Uang Beredar & 0.002788 & 0.81342 & Tidak Signifikan \\
Inflasi & $7.69 \mathrm{E}-06$ & $2.63357^{*}$ & Signifikan \\
Suku Bunga & $-9.75 \mathrm{E}-10$ & -0.78743 & Tidak Signifikan \\
Nilai Tukar & 0.331613 & $-3.17559^{*}$ & Signifikan \\
\hline
\end{tabular}

\begin{tabular}{ll}
\hline $\mathrm{t}$ tabel & $: 1.66196$ \\
Keterangan & $:$ Signifikan pada taraf nyata $5 \%$
\end{tabular}

Tabel 3. Estimasi

\begin{tabular}{cccc}
\hline Variabel & Koefisien & t-Statistik & Keterangan \\
\hline Kuala Lumpur Composite Index & 0.026120 & 0.49722 & Tidak Signifikan \\
Strait Times Index & 0.285107 & $3.66857^{*}$ & Signifikan \\
Stock Exchange of Thailand Index & -0.038563 & -0.55636 & Tidak Signifikan \\
Philippines Stock Exchange Index & 0.039376 & $2.36041^{*}$ & Signifikan \\
Dow Jones Industrial Average Index & 0.069674 & $4.47116^{*}$ & Signifikan \\
Nikkei 225Index & -0.027448 & $-3.86867^{*}$ & Signifikan \\
Shanghai Composite Index & -0.051271 & $-2.65733^{*}$ & Signifikan \\
\hline
\end{tabular}

$\mathrm{t}$ tabel

VAR model variabel indeks harga saham asing terhadap IHSG

Keterangan $\quad: *$ Signifikan pada taraf nyata $5 \%$

Berdasarkan hasil pada Tabel 3 diketahui dari t-statistik harga saham asing, hanya Kuala Lumpur Composite Index dan Stock Exchange of Thailand Index yang tidak signifikan mempengaruhi IHSG. t-statistik Strait Times Index (3.66857),Philippines Stock Exchange Index (2.36041), dan Dow Jones Industrial Average Index (4.47116) diketahui signifikan dan positif berpengaruhi terhadap IHSG. Nikkei 225 Index dan Shanghai Composite Index diketahui signifikan berpengaruh dengan arah pengaruh negatif terhadap IHSG.

\section{PEMBAHASAN}

\section{Pengaruh Variabel MakroekonomiTerhadap IHSG}

Berdasarkan pengujian dapat ditarik sebuah kesimpulan bahwa Indeks Produksi Industri (proksi pertumbuhan ekonomi) dan inflasi berpengaruh positif terhadap kinerja IHSG sedangkan nilai tukar berpengaruh negatif terhadap IHGS di Bursa Efek Indonesia. Semakin meningkatnya indeks produksi industri akan mendorong pertumbuhan sektor rill dan meningkatkan kinerja perusahaan. Peningkatan kinerja perusahaan tersebut akan turut berkontribusi terhadap pertumbuhan kinerja IHSG di Bursa Efek Indonesia. Sebagaimana Kabir dan Masih (2014) menyatakan peningkatan pertumbuhan ekonomi Negara pada gilirannya akan meningkatkan produksi industri yang akan meningkatkan arus kas perusahaan dan berdampak pada peningkatan harga saham. emuan ini sejalan dengan penelitian yang dilakukan oleh Naik dan Pahdi (2012), Hussin et al. (2012) dan Kalyanaraman dan Tuwarji (2014).

Kenaikan inflasi yang signifikan akan membuat IHSG mengalami penurunan (bearish). Hal ini dikarenakan peningkatan inflasi akan berpengaruh langsung terhadap biaya produksi dan berpengaruh pada laba perusahaan, namun dalam penelitian ini peningkatan inflasi akan direspon dengan peningkatan IHSG. Selama periode penelitian inflasi mengalami fluktuasi yang cukup tinggi, Apabila dikaitkan dengan teori investasi yang menyatakan risk dan return bergerak positif, maka jika terjadi peningkatan inflasi, hargaharga akan cenderung naik, profit perusahaan meningkat dan investor akan mendapatkan return dividen yang lebih tinggi. Selain itu, 
investor akan mendapatkan keuntungan dari capital gain karena mendapatkan untung dari peningkatan harga saham. Keadaan ini akan turut meningkatkan harga saham perusahaan sehingga meningkatkan IHSG.Hasil temuan penelitian ini sejalan dengan Hussin et al (2012) dan Sikalao-Lekobane (2014) yang menyatakan inflasi berpengaruh positif terhadap indeks harga saham.

Penelitian ini menunjukkan tekanan volatilitas nilai tukar juga turut mempengaruhi kinerja IHSG di Bursa Efek Indonesia. Depresiasi nilai tukar rupiah terhadap dollar AS mendorong para investor memindahkan dananya dari saham domestik ke saham asing, guna mendapatkan pengembalian yang lebih tinggi. Depresiasi mata uang domestik juga akan menjadikan investor asing mengalihkan dananya ke pasar valuta asing untuk mendapatkan keuntungan yang lebih tinggi. Depresiasinya nilai mata uang domestik akan berdampak pada biaya operasional perusahaan dan persaingan internasional perusahaan yang akan turut mempengaruhi laba dan harga saham perusahaan (Tandelilin, 2010). Temuan ini sejalan dengan hasil penelitian Hussin et al (2012), Sikalao-Lekobane (2014), Yu Hsing (2014), Kabir dan Masih (2014) serta Ibrahim dan Musah (2014) yang menyatakan bahwa nilai tukar mata uang berpengaruh negatif terhadap indeks harga saham di negaranya.

Suku bunga yang semakin meningkat semakin menandakan perekonomian yang cukup ketat. Jones (2013) menyatakan suku bunga dan harga saham memiliki hubungan yang terbalik, dalam arti semakin meningkatnya suku bunga maka semakin menurunnya harga saham, namun dalam penelitian ini suku bunga tidak berpengaruh signifikan pada IHSG. Hal ini dikarenakan investor menganggap suku bunga tidak menjadi alternatif pendapatan selain saham, peningkatan suku bunga dianggap masih cukup rendah bila dibandingkan dengan tingkat return yang akan didapatkan oleh investor di pasar saham. Hasil ini sesuai dengan penelitian Ho (2011), Naik danPadhi (2012) yang menyatakan suku bunga tidak berpengaruh terhadap IHSG

Penelitian ini pula menunjukkan penigkatan jumlah uang beredar tidak berpengaruh signifikan terhadap perubahan IHSG. Bila dihubungkan dengan tujuan memegang uang, motif utama seseorang dalam menggunakan uang adalah transaksi dan kebutuhan sehari - hari bukan berinvestasi.
Muharam dan Nurafni (2008) menyatakan bila dihubungkan dengan perilaku investasi masyarakat Indonesia, pasar modal bukalah sarana investasi utama melainkan investasi pada perbankan maupun sektor rill, sehingga peningkatan jumlah uang beredar tidak akan mempengaruhi IHSG. Temuan ini tidak konsisten dengan penelitian Naik dan Padhi (2012) dan Kalyanaraman dan Tuwarji (2014) yang menyatakan peningkatan jumlah uang beredar akan meningkatkan indeks harga saham.

\section{Pengaruh Indeks Harga Saham Asing Terhadap IHSG}

IHSG tidak lepas dengan pengaruh makroekonomi negara lain yang direfleksikan dengan indeks harga saham asing. IHSG merespon positif perubahan dari Strait Times Index, Philippines Stock Exchange Index dan Dow Jones Industrial Average Index. Kenaikan signifikan dari ketiga indeks harga saham tersebut dapat membuat kondisi IHSG mengalami peningkatan (bullish).Hal ini dikarenakanIndonesia yang merupakan emerging market dan komposisi investor asing lebih dari 60 persen, menjadikan Indonesia sangat rentan dengan perubahan dan risiko dari Dow Jones Industrial Average Index, Strait Times Index dan Philippines Stock Exchange Index. Pengaruh inijuga dapat berasal kerjasama ekonomi antar Negara. Hal ini terlihat pada perusahaan - perusahaan yang terdaftar di ketiga index tersebut juga terdaftar pada BEI selain itu juga beberapa perusahaan di Indonesia memiliki struktur kepemilikan asing.Hasil ini turut mengkonfirmasi temuan Kabir dan Masih (2014), Vardhan dan Sinha (2015) yang menyatakan indeks harga saham Amerika Serikat mempengaruhi indeks harga saham di negaranya serta mengkonfirmasi temuan penelitian Pasaribu dan Kowanda (2013) yang menyatakan indeks harga saham Singapura mempengaruhi IHSG.

Penelitian ini menunjukkan perubahan pada Kuala Lumpur Composite Index dan Stock Exchange of Thailand tidak berpengaruh terhadap pergerakan IHSG. Hal ini dikarenakan kondisi politik dan ekonomi yang mempengaruhi iklim bisnis dan investasi di Malaysia dan Thailand sehingga secara langsung berpengaruh terhadap indeks harga saham disana. Berbeda dengan Indonesia yang memiliki politik dan ekonomi yang lebih stabil, sehingga menawarkan kemanan dan kepastian investasi bagi investor. Temuan ini tidak sejalan dengan hasil penelitian yang dilakukan oleh 
Pasaribu dan Kowanda (2013) yang menyatakan bahwa Kuala LumpurComposite Index berpengaruh terhadap IHSG.

Penelitian juga membuktikan indeks harga saham dari negara maju dapat memberi arah pengaruh negatif terhadap IHSG, yang merupakan emerging market. Nikkei 225 index dan Shanghai Composite Index diketahui berpengaruh negatif terhadap IHSG. Hasil dapat di sebabkan selama periode penelitian Jepang dan Cina mengalami perlemahan ekonomi, Jepang yang dilanda deflasi berkepanjangan dan Cina yang terus menerung mengalami penurunan nilai ekspor, menyebabkan penurunan pada indeks harga saham di Negara tersebut, yaitu Nikkei 225 index dan Shanghai Composite Index. Berbeda dengan Indonesia yang merupakan emerging market dapat terus tumbuh dan berkembang seiring perkembangan perekonomian global dan domestik serta berdampak pada naiknya IHSG. Hasil ini konsisten dengan temuan Chien et al, (2015) yang menjelaskan bahwa indeks harga saham Cina berhubungan signifikan negatif dengan indeks harga saham Indonesia.

\section{KESIMPULAN}

Penelitian ini menguji pengaruh variabel makroekonomi dan indeks harga saham asing terhadap Indeks Harga Saham Gabungan (IHSG) selama periode Januari 2008 - Desember 2015. Peningkatan indeks produksi industri dan inflasi akan meningkatkan IHSG. Depresiasinya nilai tukar rupiah terhadap dollar Amerika Serikat akan meningkatkanIndeks Harga Saham Gabungan. Perubahan pada jumlah uang beredar dan tingkat suku bunga tidak berpengaruh terhadap Indeks Harga Saham Gabungan. Peningkatan Singapore Strait Times Index, Philippines Stock Exchange Index dan Dow Jones Industrial AverageIndex akan meningkatkan Indeks Harga Saham Gabungan. Sebaliknya peningkatan Nikkei 225 Index dan Shanghai Composite Index akan menurunkan Indeks Harga Saham Gabungan. Perubahan pada Kuala Lumpur Composite Index, Stock Exchange of Thailand Index tidak berpengaruh terhadap Indeks Harga Saham Gabungan.

\section{SARAN}

1. Bagi investor, dalam pengambilan keputusan investasi lebih memperhatikan faktor-faktor seperti inflasi, nilai tukar dan suku bunga serta pergerakan harga saham asing yang telah terbukti mempengaruhi
IHSG.

2. Bagi pemerintah, dalam mejaga stabilitas perekonomian sebaiknya berhati-hati terhadap pengaruh dari sisi global yaitu harga saham asing dan menerapkan kebijakan yang cepat dan tepat untuk menstabilkan perekonomian karena IHSG juga dapat dipengaruhi oleh IHSG.

3. Bagi penelitian selanjutnya, diharapkan dapat mempertimbangkan hal atau faktorfaktor lainnya yang dapat mempengaruhi IHSG. Faktor-faktor yang dikiranya dapat mempengaruhi IHSG antara lain, cadangan devisa, suku bunga The Fed, harga minyak dunia dan sebagainya. serta diharapkan agar memperbanyak rentang periode penelitian untuk mendapatkan hasil yang lebih baik.

\section{DAFTAR PUSTAKA}

Ajija, S.R., Sari, D.W., Setianto., Primanti. 2011. Cara Cerdas Menguasai EViews. Salemba Empat. Jakarta.

Ariefinto, M.D. 2012. Ekonometrika : Esensi dan Aplikasi dengan Menggunakan Eviews. Erlangga. Jakarta.

Beik, Irfan Syauqi., Sri Wulan Fatmawati. 2014. Pengaruh Indeks Harga Saham Syariah Internasional dan Variabel Makro Ekonomi Terhadap Jakarta Islamic Index. Al-Iqtishad Jurnal. Vol. VI, No.2.

Bodie., Kane., Marcus. 2014. Manajemen Portofolio dan Investasi. Edisi kesembilan.

Chien, Mei-Se., Chien-Chiang Lee., Te-Chung Hu., Hui-Ting Hu. 2015. Dynamic Asian Stock Market Convergence : Evidence from Dynamic Cointegration Analysis among China and ASEAN-5. Journal of Economic Modelling. Vol. 51, p. 84-98.

Dornbusch R, Fischer dan Startz,(2008),Makroekonomi. $\quad$ R. $\quad$ I. Mirazudin [Penerjemah],PT. Media Global Utama, Jakarta.

Gujarati, D.N., Porter, D.C. 2012. Basics Econometric. R. Dasar-Dasar Ekonometrika. Edisi Kelima. Salemba Empat. Jakarta.

Hartono, Jogianto. 2015. Teori Portofolio dan Analisis Investasi. Edisi Kesepuluh. BPFE UGM. Yogyakarta.

Ho, Catherine. 2011. Domestic Macroeconomic Fundamentals and World Stock Market Effects on ASEAN Emerging Markets. Int Journal of Economic and Management. Vol. 5 (1), p. 1-18. 
Hsing, Yu. 2014. Impacts of Macroeconomic Factors on the Stock Market in Estonia. Journal of Economic and Development Studies. Vo. 2, No. 1, pp. 23-31.

Husnan, Suad. 2015. Teori Portofolio dan Analisis Sekuritas. Edisi Kelima. UPP STIM YKPN. Yogyakarta

Hussin, et al. 2012. Macroeconomic Variables and Malaysian Islamic Stock Markets : A Time Series Analysis. Journal of Business Studies Quarterly. Vol. 3, No. 4, p.1-13.

Ibrahim, Muazu., Alhassan Musah. 2014. An Econometric of the Impact of Macroeconomic Fundamentals on Stock Market Return in Ghana. Reasearch in Applied Economics. Vol. 6, No. 2.

Jones, Charles. 2013. Investments : Analysis and Management. Twelve Edition. Library of Congress Cataloging-in-Publication Data. United States of America.

Kabir, Humayun., Mansur Masih. 2014. Dynamic Integration of Domestic Equity Price, Foreign Equity Price and Macroeconomic Indicators: Evidence from Malaysia. Munich Personal RePEc Archive Paper. No. 57007

Kalyanaraman, Lakshmi., Basmah Al Tuwarji. 2014. Macroeconomic Forces and Stock Prices : Some Empirical Evidence from Saudi Arabia. International Journal of Financial Research. Vol. 5, No.1, p. 81-92.

Kumari, Jyoti., Jitendra Mahakud. 2015. Relationship Between Conditional Volatility of Domestic Macroeconomic Factors and Conditional Stock Market Volatility: Some Further Evidence from India. Asia-Pacific Finance Market. Vol. 22, p. 87-111.

Madura. 2009. International Corporate Finance. Salemba Empat. Jakarta.

Mankiw NG,2012,Teori Makroekonomi. Imam [Penerjemah],Erlangga, Jakarta.

Muharam, Harjum., Zuraedah Nurafni. 2008. Pengaruh Variabel Makroekonomi terhadap Indeks Harga Saham Gabungan di BEJ. Jurnal Manajemen Akutansi dan Sistem Informasi. Vol. 8, No. 1.

Naik, Kumar., Puja Padhi. 2012. The Impact of Macroeconomic Fundamentals on Stock Prices Revisited : Evidence from Indian Data. Eurasian Journal of
Business and Economics. Vol. 5 (10), p. 25-44.

Pasaribu, Rowland., Dionysia Kowanda. 2013. Dinamika bursa Saham Asing dan Makroekonomi terhadap Indeks Harga Saham Gabungan Bursa Efek Indonesia. Jurnal Akutansi dan Bisnis. Vol.14, No. 1, p. 89-112.

Sikalao-Lekobane, Onneetse., Khaufelo Lekobane. Do Macroeconomic Variables Influence Domestic Stock Market Price Behavior in Emerging Markets? A Johansen Approach to the Botswana Stock Market. Journal of Economic ad Behavioral Studies. Vol. 6, No. 5, p. 363-372.

Sirucek, Martin. 2012. Macroeconomic variables and stock market: US review. Munich Personal RePEc Archive. No. 39094

Tandelilin, Eduardus. 2010. Portofolio dan Investasi : Teori dan Aplikasi. Edisi Pertama. Kanisius. Yogyakarta

Vardhan, Harsh., Pankaj Sinha. 2015. Influence of Macroeconomic Variable on Indian Stock Movement : Cointegration Approach. Munich Personal RePEc Archive 